\title{
Selection Efficiency for Grain Yield Under Normal Irrigation and Water Stress Conditions in Bread Wheat
}

Ayman Gamal Abd El-Rady

Wheat Res. Dep., Field Crops Res. Inst., ARC, Giza, Egypt.

Received on: 3/5/2017

Accepted for publication on: 8/5/2017

\begin{abstract}
The objective of the present research was to study the efficiency of pedigree selection for grain yield/plant under normal irrigation and water stress conditions. Two cycles of pedigree selection for grain yield/plant were practiced separately under normal irrigation and water stress conditions. The base population was the $\mathrm{F}_{3}$ population of Sids 1/Misr 1. In the third year, selections under normal irrigation and water stress were evaluated at both environments. The phenotypic was slightly larger than the genotypic variance, and generally decreased from the $\mathrm{F}_{3}$ to the $\mathrm{F}_{5}$ generation. Broad-sense heritability was 87.08 and $85.38 \%$ under normal irrigation compared to 84.88 and $82.40 \%$ under water stress after cycle 1 and 2 , respectively. The realized heritability was 40.08 and $67.40 \%$ under normal irrigation compared to 40.19 and $78.47 \%$ under water deficit after cycle1 and 2, respectively. The average observed gains of normal irrigation selections were 19.58 and $23.66 \%$ from bulk sample and 7.93 and $8.73 \%$ from the better parent, while the average observed gains of water stress selections were 26.44 and $32.57 \%$ from bulk sample and 14.12 and $16.57 \%$ from the better parent, when evaluation practiced under normal irrigation and water stress, respectively. The results indicated that the antagonistic selection was better than synergistic selection in changing the mean and decreased the sensitivity. Grain yield/plant revealed positive and high phenotypic correlation with each of biological yield/plant, number of spikes/plant and number of kernels/spike under normal irrigation and water stress, and 100-kernel weight under water stress in the base population and after two cycle of selection for grain yield/plant. The results of path-coefficient analysis revealed that number of spikes/plant had the highest positive direct effect on grain yield/plant followed by number of kernels/spikes and 100-kernel weight after two cycle of pedigree selection for grain yield/plant under normal irrigation and water stress conditions.
\end{abstract}

Keywords: pedigree selection, selection response, drought susceptibility, synergistic vs. antagonistic, correlation, path-coefficient, wheat.

\section{Introduction}

Wheat is one of the most important cereal crops all over the world and the main food crop in Egypt. The cultivated area in Egypt reached 3.4 million feddans in 2014/2015 growing season, with an average yield of $18.00 \mathrm{ardab} /$ feddan, and the total production was about 9.47 million tons (Economic Affairs Annual Report,
2015). Water stress is one of the main abiotic stresses and an important factor for reducing yield of cultivated plants in semi arid agricultural lands (Amin-Alim, 2011). Therefore, breeding programs should aim at developing high yielding cultivars over a wide range of stress and non-stress environments. The efficiency of a breeding program for drought toler- 
ance depends largely on the selection criteria and selection method used to achieve genetic improvement through selection, in addition to the complexity of drought itself (Passioura, 2007). Pedigree selection can be used to identify superior genotypes for grain yield in a cultivar development program. Several workers indicated that pedigree selection is effective method in improving grain yield (Kheiralla et al. 1993; Ismail, 1995; Tammam et al. 2004; Ahmed, 2006; Ali, 2011 and Mahdy et al. 2012). Breeding for drought tolerance should focus on increasing genetic variance and choosing a selection environment that is representative of the target environment. Some researchers believe in selection under favorable conditions (Betran et al. 2003), other prefer selection in a target stress condition (Rathjen, 1994), while other yet have chosen a mid-point and believe in selection under both favorable and stress conditions (Byrne et al. 1995). Jinks and Connolly (1973 and 1975), Jinks and Pooni (1982) and Falconer (1990) indicated that, environmental sensitivity was reduced if selection and environment effects were in opposite direction, while sensitivity was increased if selection and environ- ment effects were in the same direction. Correlation coefficient is an important statistical tool which can help wheat's breeders to select the genotypes of high yield. Path analysis divides the correlation coefficients into direct and indirect effects. Consequently, correlation studies along with path analysis provide a better understanding of the association of different traits with grain yield.

The objectives of the present research were to study; 1) the efficiency of pedigree selection for grain yield/plant under normal irrigation and water stress conditions, 2) the sensitivity of selected lines to water stress, and 3) the correlation and path coefficient for yield and its components in the base population and cycle two of selection under normal irrigation and water stress.

\section{Materials and Methods}

The present research was carried out at Shandaweel Agric. Res. Station, Agricultural Research Center (ARC), Egypt during 2013/2014 to $2015 / 2016$ growing seasons. The breeding materials used were $100 \mathrm{~F}_{3}$ families traced back to 100 random $\mathrm{F}_{2}$ plants originated from the cross (Sids $1 \times$ Misr 1 ). The pedigree of the parents is presented in Table 1 .

Table 1. The pedigree of the parents of the wheat population.

\begin{tabular}{|l|l|}
\hline Parent & \multicolumn{1}{c|}{ pedigree } \\
\hline Sids 1 & HD 2172 / PAVON"S" // 1158.57 / MAYA 74"S" \\
\hline Misr 1 & OASIS/KAUZ//4*BCN/3/2*PASTOR. \\
\hline
\end{tabular}

In $2013 / 2014$ season $\left(F_{3^{-}}\right.$ generation); $100 \mathrm{~F}_{3}$ families, original parents and $\mathrm{F}_{3}$ bulked random sample (a mixture of equal number of grains from each plant to represent the generation mean) were sown in two field experiments using a randomized complete block design with three replications. The experiment under normal irrigation was grown in supplemental water applied regularly as recommended, while the experiment 
under water stress did not receive any irrigation after the second irrigation (planting irrigation and two irrigations throughout the growing season). Each plot consisted of a single row $3 \mathrm{~m}$ long, $30 \mathrm{~cm}$ apart and $10 \mathrm{~cm}$ between grains within row. The recommended cultural practices for wheat production were adopted throughout the growing season in the two experiments. At the end of the season, separate analysis of variance of the two treatments was applied on a plot mean basis. The best 20 high yielding plants from the best 20 high yielding families were saved to give the $\mathrm{F}_{4}$ families in each environment.

In $2014 / 2015$ season $\left(F_{4}-\right.$ generation); the $20 \quad \mathrm{~F}_{4}$ families selected under normal irrigation with the parents and $F_{4}$ bulk sample were sown under normal irrigation and the $20 \mathrm{~F}_{4}$ families selected under water stress with the parents and $\mathrm{F}_{4}$ bulk sample were sown under water stress. The experimental design, number of replications and cultural practices were properly adopted as the same in the first season. Data were recorded as previously mentioned. At the end of season, each group of families (20 families) for each environment of selection was analyzed separately. The best 10 high yielding plants from the best 10 high yielding families were saved in each environment to give the $\mathrm{F}_{5}$ families.

In $2015 / 2016$ season $\left(F_{5^{-}}\right.$ generation); the 10 high yielding $\mathrm{F}_{5}$ families selected under normal irrigation + the 10 high yielding $\mathrm{F}_{5}$ families selected under water stress environment + the two parents + the bulk sample were evaluated under both environments. Data were recorded on ten guarded plants from each family. The studied traits were; days to heading $(\mathrm{DH})$, days to maturity (DM), plant height $(\mathrm{PH}, \mathrm{cm})$, number of spikes/plant (NS/P), number of kernels/spike (NK/S), 100-kernel weight (100-KW, g), grain yield/plant (GY/P, g) and biological yield/plant (BY/P, g).

\section{Statistical analysis:}

Data were subjected to proper statistical analysis according to Steel and Torrie (1980). Two analysis of variance were done, the first was for (families + parents + bulk sample), and the second was for the selected families to calculate heritability, genotypic and phenotypic coefficient of variations. Genotypes means were compared using Revised Least Significant Differences (RLSD) test at 5 and $1 \%$ level of probability, according to El-Rawi and Khalafala (1980). The phenotypic $\left(\sigma^{2} p\right)$ and genotypic $\left(\sigma^{2} \mathrm{~g}\right)$ variances and heritability in broad sense $(\mathrm{H} \%)$ were calculated according to Walker (1960). The phenotypic (PCV\%) and genotypic $(\mathrm{GCV} \%)$ coefficients of variability were calculated as outlined by Burton (1952), Realized heritability $\mathrm{h}^{2}=\mathrm{R} / \mathrm{S}$ was calculated according to Falconer (1989); where $\mathrm{R}=$ response to selection and $\mathrm{S}=$ selection differential. Drought susceptibility index (DSI) was computed according to the method of Fischer and Maurer (1978). The sensitivity and relative merits of selected families were assessed as described by Falconer (1990). The relative merits is expressed as the ratio change of mean by antagonistic selection / change of mean by synergistic selection. 
The phenotypic correlation coefficients via base population $\left(\mathrm{F}_{3}\right)$ and the second cycle of selection $\left(\mathrm{F}_{5}\right)$ were calculated among the studied traits as outlined by Al- Jibouri et al. (1958), as follows: Phenotypic correlation $\mathrm{rp}_{\mathrm{xy}}=\operatorname{cov} \mathrm{p}_{\mathrm{xy}} /\left(\sigma \mathrm{p}_{\mathrm{x}} \cdot \sigma \mathrm{p}_{\mathrm{y}}\right)$.

\section{Path coefficient analysis:}

Path coefficient analysis was done according to the procedure followed by Dewey and $\mathrm{Lu}$ (1959) for yield and its components under normal irrigation and water stress in the base population and the second cycle of selection. The contributions of number of spikes/plant (NS/P), number of kernels/spike (NK/S), 100kernel weight $(100-\mathrm{KW}, \mathrm{g})$, grain yield/plant $(\mathrm{GY} / \mathrm{P}, \mathrm{g})$ as well as residual factors $(\mathrm{X})$ were included in the path coefficient analysis as shown in the following diagram:
4. GY/P

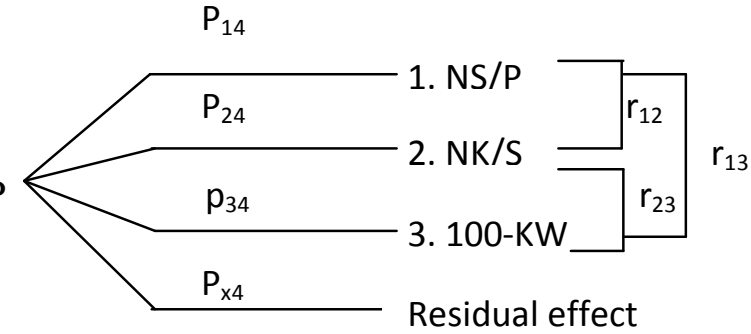

$\mathrm{r}_{14}=\mathrm{P}_{14}+\mathrm{r}_{12} \mathrm{P}_{24}+\mathrm{r}_{13} \mathrm{P}_{34}$

$\mathrm{r}_{24}=\mathrm{P}_{24}+\mathrm{r}_{12} \mathrm{P}_{14}+\mathrm{r}_{23} \mathrm{P}_{34}$

$\mathrm{r}_{34}=\mathrm{P}_{34}+\mathrm{r}_{13} \mathrm{P}_{14}+\mathrm{r}_{23} \mathrm{P}_{23}$

$1=\mathrm{P}^{2}{ }_{\mathrm{X} 4}+\mathrm{P}^{2}{ }_{14}+\mathrm{P}^{2}{ }_{24}+\mathrm{P}^{2}{ }_{34}+2 \mathrm{P}_{14} \mathrm{r}_{12} \mathrm{P}_{24}+2 \mathrm{P}_{14} \mathrm{r}_{13} \mathrm{P}_{34}+2 \mathrm{P}_{24} \mathrm{r}_{23} \mathrm{P}_{34}$

Fig. 1: Direct and indirect of NS/P, NK/S, 100-KW and GY/P

\section{Results and Discussion}

\section{Description of the base} population:

The analysis of variance (Table

2) indicated highly significant differences among the $F_{3}$ families for all studied traits under normal and water stress environments, indicating that selection in the base population would be effective. Comparing the population mean for grain yield/plant with mean of the two parents indicates over-dominance under normal irrigation, in which population mean $(21.39 \mathrm{~g})$ out yielded the higher yielding parent, Misr 1 (20.53 g) and tended to show complete dominance $(16.12 \mathrm{~g})$ towards the higher parent Sids 1 (16.44 g) under water stress. The reduction caused by water stress in the $\mathrm{F}_{3}$ families was $7.79,5.43$, $5.53,11.91,6.07,9.62,24.64$ and $25.43 \%$ for days to heading, days to maturity, plant height, number of spikes/plant, number of kernels/spike, 100-kernel weight, grain yield/plant and biological yield/plant, respectively. Mahdy (2012) noted average reduction caused by drought stress of $13.68,6.38$. 12.10, 0.74 and 5.21\% for plant height, number of spikes/plant, grain yield /plant, number of grain/spike and 100 grain weight. Soliman et al. (2015) came to the same conclusion. The phenotypic (P.C.V.\%) and genotypic (G.C.V.\%) coefficient of variations were sufficient for selection in the base population, and ranged from (2.95 $20.64 \%)$ and $(2.89-20.20 \%)$ under 
normal irrigation, and from (3.00 $19.15 \%)$ and $(2.92-18.20 \%)$ under water stress; for days to maturity and grain yield/plant, respectively. These results indicates that selection among $\mathrm{F}_{3}$ families for grain yield could be effective. These findings are in line with those reported by Ismail (1995), Zakaria et al. (2008), El-Morshidy et al. (2010), Ali (2011), Abd-ElHaleem et al. (2012), Mahdy (2012), Ahmed et al. (2014) and Soliman et al. (2015). Heritability estimate is considered one of the most important parameters for selection response in early generations. Estimates of broad sense heritability were high for all studied traits, and slightly higher under normal irrigation than under wa- ter stress. Estimates of broad sense heritability at one location in one year were biased upward due to confounding the effects of locations and years with the genetic variances estimates (O’Brien et al. 1978). In general, high estimates of broad sense heritabilities (Table 2) indicate that the environmental effects were small compared to genetic effects. These results are in line with those reported by Kashif and Khaliq (2004), Cheema et al. (2006) and Zakaria et al. (2008). Salous et al. (2014) and Soliman et al. (2015) found that heritability estimate for grain yield under non-stress conditions was slightly higher than that under stress conditions.

Table 2. Means, Mean squares, phenotypic (P.C.V\%) and genotypic (G.C.V.\%) coefficients of variability and heritability in broad sense $(\mathrm{H} \%)$ for the studied traits in the base population $\left(F_{3}\right)$ under normal irrigation and water stress environments.

\begin{tabular}{|c|c|c|c|c|c|c|c|c|c|c|c|c|}
\hline \multirow[b]{2}{*}{ Env. } & \multirow{2}{*}{ Trait } & \multicolumn{3}{|c|}{ Mean Squares } & \multicolumn{4}{|c|}{ Mean } & \multirow{2}{*}{\begin{tabular}{|c|} 
Reduction \\
$\%$
\end{tabular}} & \multirow{2}{*}{$\begin{array}{c}\text { P.C.V. } \\
\%\end{array}$} & \multirow{2}{*}{$\begin{array}{c}\text { G.C.V. } \\
\%\end{array}$} & \multirow{2}{*}{$\begin{array}{l}\text { H } \\
\%\end{array}$} \\
\hline & & Reps. & Families & Error & $\mathbf{F}_{3}$ & Bulk & $\mathbf{P}_{1}$ & $\mathbf{P}_{2}$ & & & & \\
\hline \multirow{8}{*}{ 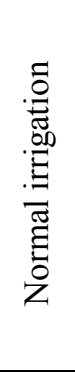 } & Days to heading & 10.36 & $66.41 * *$ & 2.01 & 96.85 & 98.33 & 94.00 & 91.00 & & 4.86 & 4.78 & 96.97 \\
\hline & Days to maturity & 16.01 & $56.14 * *$ & 2.24 & 146.49 & 148.67 & 147.00 & 144 & & 2.95 & 2.89 & 96.01 \\
\hline & Plant height ;cm & 6.80 & $93.92 * *$ & 16.76 & 106.88 & 111.33 & 115.67 & 110.33 & & 5.24 & 4.75 & 82.16 \\
\hline & No. of spikes /plant & 3.35 & $9.41 * *$ & 0.95 & 12.59 & 11.63 & 12.17 & 12.24 & & 14.07 & 13.34 & 89.90 \\
\hline & $\begin{array}{l}\text { No. of kernels } \\
\text { /spike }\end{array}$ & 2.42 & $62.09 * *$ & 4.71 & 39.89 & 37.67 & 38.28 & 39.83 & & 11.40 & 10.96 & 92.41 \\
\hline & 100- kernel weight & 0.15 & $0.290 * *$ & 0.016 & 4.26 & 4.07 & 4.14 & 4.22 & & 7.30 & 7.09 & 94.48 \\
\hline & Grain yield/plant & 9.56 & $58.46^{* *}$ & 2.47 & 21.39 & 17.67 & 19.25 & 20.53 & & 20.64 & 20.20 & 95.74 \\
\hline & $\begin{array}{l}\text { Biological yield/ } \\
\text { plant }\end{array}$ & 60.79 & 326.0 & 14.80 & 4.11 & 44.43 & 49.25 & 46.27 & & 19.27 & 18.82 & 95.46 \\
\hline \multirow{8}{*}{ 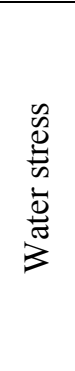 } & Days & 5.30 & $79.28 * *$ & 2.43 & 89.31 & 89.00 & 88.33 & 86.3 & 7.79 & 5.76 & 5.67 & 96.93 \\
\hline & Days to & 1.76 & $51.70 * *$ & 2.52 & 138.53 & 140.67 & 142.33 & 140.00 & & 3.00 & 2.92 & 95.13 \\
\hline & Plant height & 45.01 & $102.06 * *$ & 16.33 & 100.97 & 107.33 & 111.00 & 106.67 & 5.53 & 5.78 & 5.29 & 84.00 \\
\hline & No. of spikes /plant & 1.11 & $3.77 * *$ & 0.71 & 11.09 & 11.17 & 11.78 & 11.33 & 11.91 & 10.11 & 9.11 & 81.17 \\
\hline & $\begin{array}{l}\text { No. of kernels } \\
\text { /spike }\end{array}$ & 6.71 & $74.97 * *$ & 6.19 & 37.47 & 36.22 & 36.74 & 38.24 & 6.07 & 13.34 & 12.78 & 91.74 \\
\hline & 100- kernel weight & 0.08 & $0.270 * *$ & 0.030 & 3.85 & 3.71 & 3.81 & 3.47 & 9.62 & 7.79 & 7.35 & 88.89 \\
\hline & Grain yield/plant & 3.37 & $28.60 * *$ & 2.77 & 16.12 & 14.58 & 16.44 & 15.00 & 24.64 & 19.15 & 18.20 & 90.35 \\
\hline & $\begin{array}{l}\text { Biological yield/ } \\
\text { plant }\end{array}$ & 12.54 & $115.93 * *$ & 12.82 & 40.35 & 36.77 & 42.00 & 40.53 & 25.43 & 15.41 & 14.53 & 88.94 \\
\hline
\end{tabular}

\footnotetext{
** Significant at $1 \%$ level of probability.
} 
Results of the phenotypic correlation coefficient among all possible pairs of the studied traits in the $F_{3}$ population (Table 3) indicated positive and high phenotypic correlation between grain yield/plant and each of plant height $(0.565$ and 0.489$)$, number of spike/plant (0.851 and 0.728), number of kernels/spike (0.698 and $0.777)$, biological yield/plant $(0.960$ and 0.759 ) under normal irrigation and water stress environments, respectively and 100-kernel weight $(0.625)$ under water stress, indicating that selection for high grain yield/plant could increase these traits. However, grain yield exhibited low and positive phenotypic correlation with days to heading; 100-kernels weight under normal irrigation and days to maturity in both environments. While it indicated negative and low phenotypic correlation with days to heading under water stress conditions. Number of spikes/plant possessed positive and high phenotypic correlation with biological yield/plant under both environments and possessed positive and low with number of kernels/spike and 100kernel weight under water stress. Moreover, the phenotypic correlation between number of kernels/spike and 100-kernel weight was negative and significant (-0.342) under normal irrigation, while it was positive and significant (0.218) under water stress.

Table 3. phenotypic correlation among the studied traits in the $F_{3}$ generation under normal irrigation (above diagonal) and water stress (below diagonal) conditions.

\begin{tabular}{|c|c|c|c|c|c|c|c|c|}
\hline Trait & DH & DM & $\mathbf{P H}$ & $\mathbf{N S} / \mathbf{P}$ & NK/S & 100-KW & GY/P & BY/P \\
\hline DH & & $0.446 * *$ & $0.282 * *$ & $0.214^{*}$ & 0.042 & -0.081 & 0.152 & 0.141 \\
\hline$\overline{\mathrm{DM}}$ & $0.377 * *$ & & $0.228^{*}$ & 0.098 & -0.010 & 0.078 & 0.092 & 0.103 \\
\hline $\mathrm{PH}$ & $0.219 *$ & $0.221^{*}$ & & $0.456^{* *}$ & $0.331 * *$ & 0.154 & $0.565 * *$ & $0.572 *$ \\
\hline $\mathrm{NS} / \mathrm{P}$ & -0.043 & 0.025 & $0.284 * *$ & & $0.404 * *$ & -0.185 & $0.851 * *$ & $0.784 * *$ \\
\hline $\mathrm{NK} / \mathrm{S}$ & 0.048 & -0.007 & $0.372 * *$ & $0.262 * *$ & & $-0.342 * *$ & $0.698 * *$ & $0.629 * *$ \\
\hline $100-\mathrm{KW}$ & -0.049 & 0.047 & $0.388 * *$ & $0.368 * *$ & $0.218^{*}$ & & 0.064 & 0.133 \\
\hline GY/P & -0.004 & 0.021 & $0.489 * *$ & $0.728 * *$ & $0.777 * *$ & $0.625 * *$ & & $0.960 * *$ \\
\hline $\mathrm{BY} / \mathrm{P}$ & 0.059 & 0.094 & $0.391 * *$ & $0.696 * *$ & $0.452 * *$ & $0.547 * *$ & $0.759 * *$ & \\
\hline
\end{tabular}

\section{Selection for grain yield/plant} 2.1. Variability and heritability estimates:

After two cycles of selection for grain yield/plant, there were significant $(\mathrm{p}<0.01)$ differences among selected families for grain yield/plant and other studied traits under both environments (Table 4). These results indicating the presence of variability for further cycles of selection. Similar results were obtained by Ali (2011),
Mahdy (2012), Ahmed et al. (2014), Salous et al. (2014) and Soliman et al. (2015).

The effect of selection for two cycles on variability and heritability estimates of grain yield plant is shown in Table 5. The phenotypic and genotypic variances in grain yield/ plant was high in the $\mathrm{F}_{3}$ generation under both normal and water stress conditions and dropped rapidly after cycle one $\left(\mathrm{C}_{1}\right)$ and cycle two 
$\left(\mathrm{C}_{2}\right)$. This may be due to the increase of homozygosity in the $\mathrm{F}_{5}$ generation. The phenotypic and genotypic variances were larger under normal irrigation $(19.48,7.20$ and $6.36 \%)$ and $(18.66,6.27$ and 5.43$)$ than under water stress $(9.53,4.83$ and 5.57$)$ and (8.61, 4.10 and 4.59) in $\mathrm{C}_{0}, \mathrm{C}_{1}$ and $\mathrm{C}_{3}$, respectively. The phenotypic (P.C.V.\%) and genotypic (G.C.V.\%) coefficient of variability under normal irrigation were (20.64 and $20.20 \%$ ) for grain yield/plant in the base population and decreased to (12.16 and $11.35 \%)$ after $\mathrm{C}_{1}$ and to (10.35 and 9.56\%) after $\mathrm{C}_{2}$. Likewise, The phenotypic and genotypic coefficient of variability under water stress showed the same trend. The P.C.V.\% and G.C.V.\% under water stress were very close to those under normal irrigation. The GCV\% was slightly less than the $\mathrm{PCV} \%$ under both environ- ments. The close estimates of phenotypic and genotypic variability resulted in high estimates of broad sense heritability in the two cycle of selection. It is of interest to note that heritability estimates for grain yield /plant were 95.74 and $90.35 \%$ in the base population $\left(\mathrm{F}_{3}\right)$ and decreased to 87.08 and $84.88 \%$ after $\mathrm{C}_{1}$ and 85.38 and $82.40 \%$ after $\mathrm{C}_{2}$ under normal irrigation and water stress, respectively. This could be due to the decrease in genotypic variance due to selection However, the realized heritability increased from $\mathrm{C}_{1}(40.08$ and $40.19 \%)$ to $\mathrm{C}_{2} \quad(67.40$ and $78.47 \%$ ) under normal and under water stress conditions, respectively. These results are in agreement with those of Zakaria (2004), Ahmed (2006), Abd El-Kader (2011), Ali (2011), Mahdy (2012), Salous et al. (2014) and Soliman et al. (2015).

Table 4. Mean squares for families selected for high grain yield/plant and correlated traits in $F_{4}$ and $F_{5}$ generations under normal irrigation (N) and water stress (D) conditions.

\begin{tabular}{|c|c|c|c|c|c|c|c|c|c|c|c|}
\hline \multirow{2}{*}{$\stackrel{\Xi}{ \pm}$} & \multirow{2}{*}{$\mathbf{E}$} & \multirow{2}{*}{ S. O. V. } & \multirow{2}{*}{ d.f } & $\begin{array}{l}\text { Selection } \\
\text { criterion }\end{array}$ & \multicolumn{7}{|c|}{ Correlated traits } \\
\hline & & & & $\mathrm{GY} / \mathrm{P}$ & $\overline{\mathrm{DH}}$ & $\mathrm{DM}$ & $\mathrm{PH}$ & $\mathrm{NS} / \mathrm{P}$ & $\mathrm{NK} / \mathrm{S}$ & $100 \mathrm{KW}$ & $\mathrm{BY} / \mathrm{P}$ \\
\hline \multirow{6}{*}{$\mathbf{F}_{4}$} & & Rep. & 2 & 1.81 & 1.06 & 5.72 & 5.12 & 0.09 & 12.60 & 0.059 & 1.17 \\
\hline & $\mathbf{N}$ & Families & 19 & $21.59 * *$ & $61.85^{* *}$ & $51.72 * *$ & $81.19^{* *}$ & $6.72 * *$ & $39.83 * *$ & $0.283^{* *}$ & $126.82 * *$ \\
\hline & & Error & 38 & 2.78 & 3.40 & 3.59 & 12.94 & 1.18 & 5.41 & 0.047 & 19.66 \\
\hline & & Rep. & 2 & 3.69 & 2.72 & 3.20 & 8.32 & 0.23 & 3.49 & 0.015 & 6.16 \\
\hline & D & Families & 19 & $14.50 * *$ & $67.03^{* *}$ & $47.76^{* *}$ & $97.62 * *$ & $2.73 * *$ & $24.92 * *$ & $0.160^{* *}$ & $05.95 *$ \\
\hline & & Error & 38 & 2.19 & 5.69 & 7.18 & 15.75 & 0.36 & 4.94 & 0.05 & 20.32 \\
\hline \multirow{6}{*}{$\mathbf{F}_{5}$} & \multirow{3}{*}{$\mathbf{N}$} & Rep. & 2 & 2.37 & 8.02 & 0.45 & 0.47 & 1.52 & 3.82 & 0.031 & 25.50 \\
\hline & & Families & 19 & $19.08 * *$ & $40.10^{* *}$ & $28.75^{* *}$ & $59.48^{* *}$ & $3.40 * *$ & $13.03 * *$ & $0.112^{* *}$ & $94.46 * *$ \\
\hline & & Error & 38 & 2.79 & 4.28 & 3.90 & 10.39 & 0.74 & 3.79 & 0.029 & 14.87 \\
\hline & \multirow{3}{*}{ D } & Rep. & 2 & 3.61 & 8.75 & 0.15 & 20.82 & 0.22 & 0.20 & 0.068 & 4.84 \\
\hline & & Families & 19 & $16.70 * *$ & $35.13^{* *}$ & $23.03 * *$ & $74.11^{* *}$ & $2.42 * *$ & $15.95 * *$ & $0.108^{* *}$ & $68.60 * *$ \\
\hline & & Error & 38 & 2.92 & 4.01 & 3.52 & 16.33 & 0.46 & 3.86 & 0.025 & 15.78 \\
\hline
\end{tabular}

$\mathrm{N}=$ normal irrigation $\quad \mathrm{D}=$ water stress

** Significant at $1 \%$ level of probability. 
Table 5. Variability and heritability estimates of grain yield/plant after two cycles of selection under normal irrigation $(N)$ and water stress $(D)$ conditions.

\begin{tabular}{|c|c|c|c|c|c|c|c|c|c|c|c|c|}
\hline \multirow{2}{*}{$\begin{array}{c}\text { Selection } \\
\text { cycle }\end{array}$} & \multicolumn{2}{|c|}{$\sigma_{p}^{2}$} & \multicolumn{2}{|c|}{$\sigma^{2} g$} & \multicolumn{2}{|c|}{ P.C.V. \% } & \multicolumn{2}{|c|}{ G.C.V. \% } & \multicolumn{2}{|c|}{ H \% } & \multicolumn{2}{|c|}{$\begin{array}{c}\text { Realized } \\
\text { heritability }\end{array}$} \\
\hline & $\mathbf{N}$ & D & $\mathbf{N}$ & D & $\mathbf{N}$ & D & $\mathbf{N}$ & D & $\mathbf{N}$ & D & $\mathbf{N}$ & D \\
\hline$F_{3}\left(C_{0}\right)$ & 19.48 & 9.53 & 18.66 & 8.61 & 20.64 & 19.15 & 20.20 & 18.20 & 95.74 & 90.35 & --- & --- \\
\hline$F_{4}\left(C_{1}\right)$ & 7.20 & 4.83 & 6.27 & 4.10 & 12.16 & 12.88 & 11.35 & 11.87 & 87.08 & 84.88 & 40.0 & 40.19 \\
\hline$F_{5}\left(C_{2}\right)$ & 6.36 & 5.57 & 5.43 & 4.59 & 10.35 & $10 . .48$ & 9.56 & 9.52 & 85.38 & 82.40 & 67.40 & 78.47 \\
\hline
\end{tabular}

\subsection{Means and observed gains un- der normal irrigation evaluation:}

The two groups of families selected for high grain yield/plant for two cycles, either under normal irrigation or water stress were evaluated in the $\mathrm{F}_{5}$ generation under both environments and presented in Table 6 . The group of $\mathrm{F}_{5}$ families selected for high grain yield/plant under normal irrigation and evaluated under normal irrigation ranged from 20.29 for family No. 98 to 28.71 for family No. 56 with an average of $24.37 \mathrm{~g} / \mathrm{plant}$. The average direct observed gain from selection significantly $(\mathrm{P}<0.01)$ out yielded the bulk sample by $19.58 \%$ and from the better parent $(\mathrm{P}>0.05)$ by $7.93 \%$. Seven selected families selected for grain yield/plant showed significant or highly significant observed gain from the bulk sample ranged from 14.76 to $40.86 \%$, five of them, i.e., families No. 9, No. 49, No. 56, No. 72 and No. 77 showed significant or highly significant observed gain of 14.24, 17.52, 27.13, 16.86 and $13.25 \%$, respectively from the better parent.

The group of $F_{5}$ families which selected for high grain yield/plant under water stress and evaluated under normal irrigation ranged from 22.98 for family No. 16 to 29.62 for family No. 10 with an average of 25.77 $\mathrm{g} /$ plant. The average direct observed gain from selection significantly $(\mathrm{P}<0.01)$ out yielded the bulk sample by $26.44 \%$ and from the better parent $(\mathrm{P}<0.05)$ by $14.12 \%$. Furthermore, all the selected families except family No. 16 showed significant or highly significant observed gain from the bulk sample ranged from 15.88 to $45.35 \%$, five of them showed significant or highly significant observed gain from the better parent ranged from $11.98 \%$ for family No. 17 to $31.19 \%$ for family No. 10 .

\subsection{Correlated gains under normal irrigation evaluation:}

Direct selection for high grain yield/plant for two cycles of selection under normal irrigation and evaluation under normal irrigation (Table 7) was accompanied by insignificant correlated gain for number of spikes/plant (3.38\%), number of kernels/spike $(8.82 \%)$, days to heading ($2.53 \%)$ and plant height (-3.67\%). However, significant correlated gain was observed for 100-kernel weight $(5.95 \%)$ and biological yield/plant $(10.35 \%)$ and days to maturity $(-2.38 \%)$ from the unselected bulk sample. Respect to the correlated gain from the better parent, insignificant positive correlated gain was recorded for days to heading, days to maturity and number of kernels/spike, while insignificant negative correlated gain was recorded for plant height, num- 
ber of spikes/plant, 100-kernel weight and biological yield/plant. Selection for high grain yield/plant for two selection cycles under water stress and evaluation under normal irrigation (Table 7) was accompanied by increase of 5.80, 9.16, 9.84 and $17.98 \%$ for number of spikes/plant, number of kernels/spike, 100-kernel weight and biological yield/plant, respectively, compared to bulk sample. However, positive correlated gains for all studied traits from the better parent were obtained, except for number of spikes/plant (-0.68\%).

Table 6. Mean grain yield/plant and observed gain from the bulk sample (OG\% Bulk) and from the better parent (OG\% BP) for the selected families after two cycles of selection for grain yield under normal irrigation and water stress conditions.

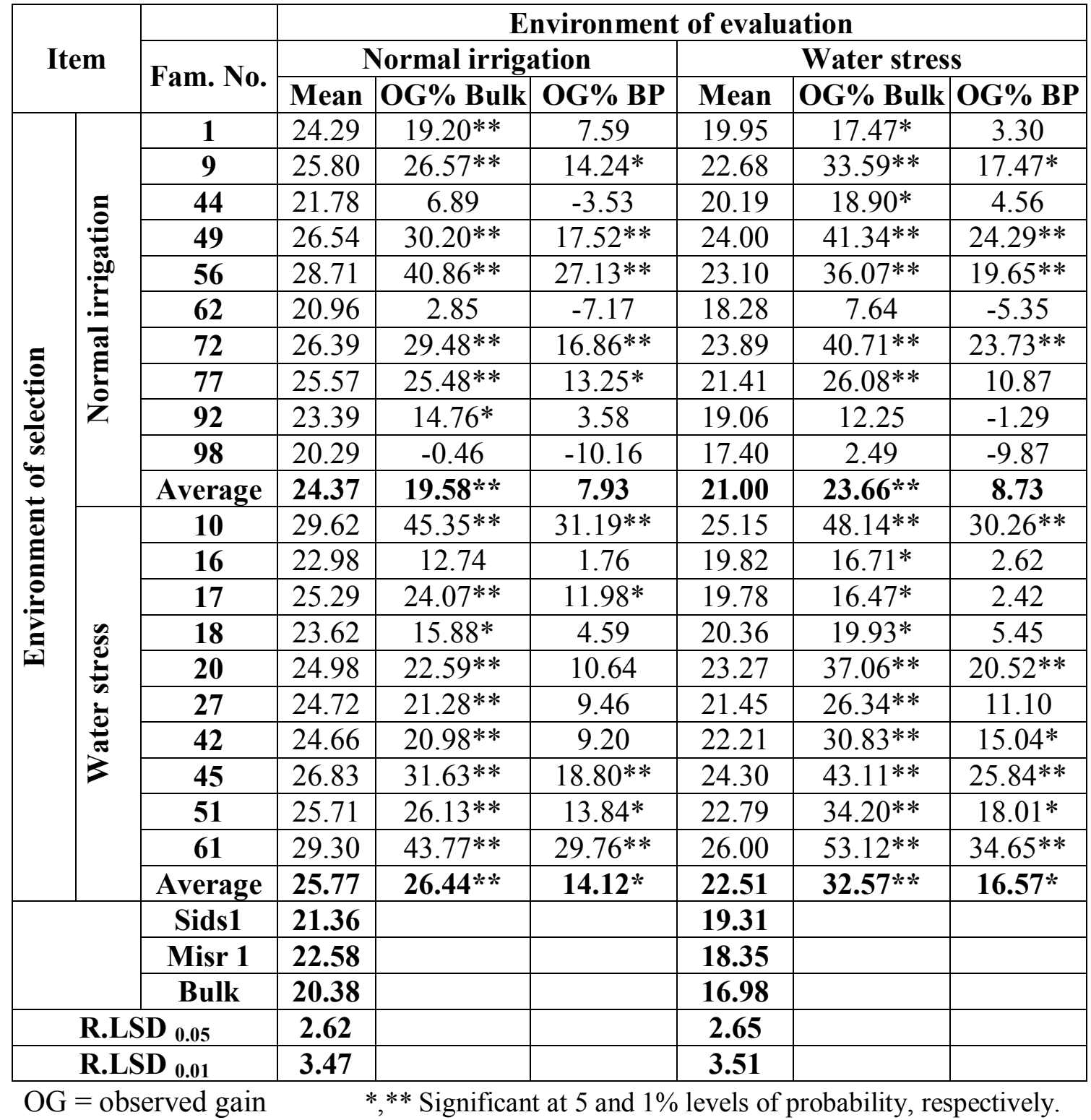


Table 7. Direct and correlated gains in the two cycles of selection for grain yield/plant in percentages from the bulk (OG\%"Bulk") and the better parent (OG\%"BP") under normal irrigation $(\mathrm{N})$ and water stress (D) conditions.

\begin{tabular}{|c|c|c|c|c|c|c|c|c|c|c|}
\hline & \multicolumn{2}{|l|}{ Item } & GY/P & $\mathrm{DH}$ & $\mathrm{DM}$ & $\mathrm{PH}$ & $\mathrm{NS} / \mathrm{P}$ & $\mathrm{NK} / \mathrm{S}$ & $100 \mathrm{KW}$ & $\mathrm{BY} / \mathrm{P}$ \\
\hline \multicolumn{3}{|c|}{$\mathrm{F}_{4}$ families $\left(\mathrm{C}_{1}\right)$} & 22.06 & 90.58 & 42.43 & 08.43 & 2.92 & 8.89 & 4.42 & 068 \\
\hline \multicolumn{3}{|c|}{ Sids 1 (P1) } & 19.93 & 93.00 & 145.00 & 7.00 & 2.00 & 8.70 & t. & .00 \\
\hline \multicolumn{3}{|c|}{ Misr 1 (P2) } & 21.08 & 88.00 & 138.67 & 112.00 & 12.43 & 0.11 & 4.27 & 4.33 \\
\hline \multirow{3}{*}{. } & \multicolumn{2}{|l|}{ Bulk sample } & 18.12 & 96.67 & 150.33 & 11.33 & 11.93 & 6.33 & .19 & 3.33 \\
\hline & \multicolumn{2}{|l|}{ OG\% (Bulk) } & $1.74 * *$ & $-6.30 * *$ & $-5.25 * *$ & -2.60 & 8.3 & 7.13 & 5.49 & $13.78^{*}$ \\
\hline & \multicolumn{2}{|l|}{$\overline{\mathrm{OG} \%(\mathrm{BP})}$} & 4.65 & 2.93 & $2.71 * *$ & -3.19 & 3.94 & -3.04 & .55 & 6.46 \\
\hline \multirow{4}{*}{ 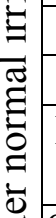 } & \multicolumn{2}{|c|}{ R.LSD $_{0.05}$} & 2.57 & 2.72 & 2.75 & 5.73 & 1.66 & 3.65 & 0.34 & 7.29 \\
\hline & \multicolumn{2}{|c|}{ R.LSD $_{0.01}$} & 3.40 & 3.57 & 3.60 & 7.58 & 2.20 & 4.83 & 0.45 & 9.64 \\
\hline & \multirow{2}{*}{$\begin{array}{c}\mathrm{F}_{5} \text { families } \\
\left(\mathrm{C}_{2}\right)\end{array}$} & $\mathrm{N}$ & 24.37 & 96.50 & 142.20 & 110.46 & 12.83 & 40.97 & 4.63 & 4.74 \\
\hline & & $\mathrm{D}$ & 25.77 & 97.66 & 142.10 & 12.30 & 13.13 & 41.10 & 4.80 & 69.22 \\
\hline & \multirow{2}{*}{\multicolumn{2}{|c|}{\begin{tabular}{|l|} 
Sids $1(\mathrm{P} 1)$ \\
Misr 1 (P2)
\end{tabular}}} & 21.36 & 98.67 & 145.00 & 16.33 & 12.05 & 38.34 & 4.64 & 63.33 \\
\hline 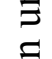 & & & 2.58 & 95.67 & 139.33 & 11.33 & 3.22 & 37.96 & 4.52 & 5.78 \\
\hline \multirow{7}{*}{ 总 } & \multicolumn{2}{|l|}{ Bulk sample } & 20.38 & 99.00 & 145.67 & 114.67 & 12.41 & 37.65 & 4.37 & 58.67 \\
\hline & \multirow{2}{*}{$\begin{array}{c}\text { OG\% } \\
\text { (Bulk) }\end{array}$} & $\mathrm{N}$ & $9.58 * *$ & -2.53 & $-2.38 *$ & -3.67 & 3.38 & 8.82 & $5.95 * *$ & 10.35 ** \\
\hline & & $\mathrm{D}$ & $44 * *$ & -1.35 & $-2.45^{*}$ & -2.07 & 5.80 & 9.16 & 9.84 & 17.98 \\
\hline & \multirow{2}{*}{$\mathrm{OG} \%(\mathrm{BP})$} & $I_{1}$ & 7.93 & 0.87 & 2.06 & -0.78 & -2.95 & 6.86 & -0.22 & -1.58 \\
\hline & & $\mathrm{D}$ & $14.12 *$ & 2.08 & 1.99 & 0.87 & -0.68 & 7.20 & 3.45 & 5.23 \\
\hline & \multicolumn{2}{|c|}{ R.LSD $_{0.05}$} & 2.62 & 3.34 & 2.97 & 5.13 & 1.42 & 3.88 & 0.31 & .64 \\
\hline & \multicolumn{2}{|c|}{ R.LSD $_{0.01}$} & 47 & 42 & & & 1.9 & 5.26 & & \\
\hline & \multicolumn{2}{|c|}{$\mathrm{F}_{4}$ families $\left(\mathrm{C}_{1}\right)$} & .06 & .27 & 8.95 & 04.78 & 11.52 & 36.21 & 4.10 & 54 \\
\hline & \multicolumn{2}{|l|}{ Sids $1(\mathrm{P} 1)$} & 12 & 90.00 & 140.00 & 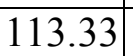 & 5 & 5.74 & .04 & 33 \\
\hline & \multicolumn{2}{|l|}{ Misr 1 (P2) } & 0 & 86.00 & 136.00 & 08.00 & 11.13 & 36.00 & .87 & 43.00 \\
\hline & \multicolumn{2}{|c|}{ Bulk sample } & 4.52 & 93.67 & 142.33 & 07.33 & 11.00 & 33.75 & 3.91 & 42.67 \\
\hline$\infty$ & OG\% (Bulk & & $17.49 *$ & $-6.83 *=$ & -2.37 & -2.38 & 4.73 & 7.29 & 4.86 & $20.79^{*}$ \\
\hline 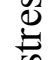 & OG\% (BP) & & 5.83 & 1.48 & 2.17 & -2.98 & 2.40 & 0.58 & 1.49 & 6.64 \\
\hline & $\mathrm{R}^{2} \mathrm{LSD}_{0.0}$ & & 2.23 & 3.44 & 4.01 & 6.32 & 0.92 & 4.51 & 0.49 & 6.81 \\
\hline 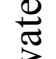 & R.LSD 0.0 & & 95 & .50 & 5.31 & 8.36 & 1.21 & 6.11 & 0.68 & 9.01 \\
\hline & $\mathrm{F}_{5}$ famili & 1 & .00 & 93.66 & 138.93 & 104.97 & 12.09 & 39.61 & 4.38 & 57.22 \\
\hline$\frac{\mathscr{O}}{0}$ & & $\mathrm{D}$ & 22.51 & 91.70 & 138.67 & 107.80 & 12.26 & 40.02 & 4.59 & 59.02 \\
\hline & Sids $1(\mathrm{P} 1)$ & & 19.31 & 95.00 & 141.00 & 113.00 & 1.66 & 37.76 & 4.45 & 58.44 \\
\hline 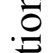 & Misr $1(\mathrm{P} 2)$ & & 35 & 00 & 6.67 & 107.33 & 11.45 & 37.24 & 4.31 & 55.25 \\
\hline है & Bulk sam & & 16.98 & 94.67 & 142.33 & 110.00 & 12.00 & 35.03 & 4.10 & 51.56 \\
\hline & $\overline{\mathrm{OG}} \%$ & 1 & $3.66^{* *}$ & -1.07 & $-2.39 *$ & -4.57 & 0.75 & $13.07 * *$ & 6.83 & 10.98 \\
\hline 1 & (Bulk) & $\mathrm{D}$ & $32.57 * *$ & -3.14 & $-2.57 *$ & -2.00 & 2.17 & $14.25 * *$ & $11.95 * *$ & $14.49^{*}$ \\
\hline & & $\mathrm{N}$ & 8.73 & 0.71 & 1.65 & -2.20 & 3.69 & 4.90 & -1.57 & -2.09 \\
\hline & & $\mathrm{D}$ & $16.57 *$ & -1.40 & 1.46 & 0.44 & 5.15 & 5.99 & 3.15 & 1.01 \\
\hline & & & & 5.00 & 2.86 & 6.83 & 1.04 & 3.42 & 0.32 & 7.41 \\
\hline & R.LSD & & 3.51 & 4.05 & 3.79 & 9.14 & 1.37 & 4.57 & 0.43 & 10.05 \\
\hline
\end{tabular}

$\mathrm{N}=$ group selected under normal irrigation $\quad \mathrm{D}=$ group selected under water stress $\mathrm{OG}=$ observed gain $\quad *, * *$ significant at 5 and $1 \%$ levels of probability, respectively

2.4. Means and observed gains under water stress evaluation:
The group of $\mathrm{F}_{5}$ families which selected for high grain yield/plant for two cycle under nor- 
mal irrigation and evaluated under water stress ranged from 17.40 for family No. 98 to 24.00 for family No. 49 with an average of $21.00 \mathrm{~g} / \mathrm{plant}$ (Table 6). The average direct observed gain from selection was highly significant (23.66\%) from the bulk sample and it was not significant $(8.75 \%)$ from the better parent. Furthermore, seven selected families which selected for grain yield/plant showed significant or highly significant observed gain from the bulk sample ranged from 17.47 to $41.34 \%$, four of them, i.e., families No. 9, No. 49, No. 56 and No. 72 showed significant or highly significant observed gain of $17.47,24.29,19.65$ and $23.73 \%$, respectively from the better parent.

Mean of the group of $\mathrm{F}_{5}$ families which selected for high grain yield/plant under water stress and evaluated under water stress ranged from 19.78 for family No. 17 to 26.00 for family No. 61 with an average of $22.51 \mathrm{~g} /$ plant. The average direct observed gain from selection, significantly $(\mathrm{P}<0.01)$ out yielded the bulk sample by $32.57 \%$ and from the better parent $(\mathrm{P}<0.05)$ by $16.57 \%$. All the selected families showed significant or highly significant observed gain from the bulk sample ranged from 16.47 for family No. 17 to $53.12 \%$ for family No. 61, six of them showed significant or highly significant observed gain from the better parent and ranged from 15.04\% for family No. 42 to $34.65 \%$ for family No.61.

\subsection{Correlated gains under water stress evaluation:}

Selection for high grain yield/plant for two cycles of selection under normal irrigation and evaluation under water stress (Table 7) showed significant correlated gain for number of kernels/spike (13.07\%) and days to maturity $(-2.39 \%)$, while showed insignificant correlated gain for days to heading $(-1.07 \%)$, plant height $(-4.57 \%)$, number of spikes/plant $\quad(0.75 \%), \quad 100$-kernel weight $(6.83 \%)$ and biological yield/plant $(10.98 \%)$ than the bulk sample. However, positive correlated gains of $0.71,1.65,3.69$ and $4.90 \%$ for days to heading, days to maturity, number of spikes/plant and number of kernels/spike and negative correlated gains of $-2.20,-1.57$ and $-2.09 \%$ for plant height, 100-kernels weight and biological yield/plant, respectively, were obtained from the better parent

Direct selection for high grain yield/plant for two cycles of selection under water stress and evaluation under water stress was accompanied by significant decrease for days to maturity $(-2.57 \%)$; insignificant decrease for days to heading $(-3.14 \%)$ and plant height $(-2.00 \%)$ from bulk sample; significant increase for number of kernels/spike (14.07\%), 100-kernel weight $(11.95 \%)$ and biological yield/plant (14.49\%) and insignificant increase for number of spikes/plant $(2.17 \%)$ from bulk sample. However, positive correlated gains for all studied traits from the better parent were obtained, except days to heading ($1.40 \%$ ). These results indicated that pedigree method of selection was effective in isolating high yield genotypes and the direct selection for grain yield per se was effective. Generally, it can be concluded that selection for high grain yield/plant for two cycles under water stress was better 
than selection under normal irrigation either evaluation was practiced under normal irrigation or under water stress. These results are in line with those reported by many investigators. Ismail (1995) reported genetic gains in grain yield over the bulk sample and the better parent of 8.47 and 4.86 in a population and 6.96 and $6.41 \%$ in another population, respectively. Attia (2003), Zakaria (2004) and Ahmed (2006) came to the same conclusion. Kheiralla et al. (2006) after two cycles of selection for grain yield/plant achieved genetic gain of 20.21 and $7.62 \%$ from the bulk sample and the better parent, respectively. Ali (2011) indicated that pedigree selection for grain yield was effective in increasing grain yield. Mahdy (2012) concluded that selection for high grain yield/plant for three cycles under drought stress was better than selection under normal irrigation either evaluation was practiced under normal irrigation or under drought stress. Salous et al. (2014) and Soliman et al. (2015) are in line with our results.

\subsection{Average observed gain from selection for grain yield/plant in two cycles:}

The observed gain from selection for high grain yield/plant under normal irrigation (Table 7) was 21.74 and $4.65 \%$ for cycle 1 and 19.58 and $7.93 \%$ for cycle 2 from the bulk sample and the better parent, respectively. The observed gain from selection for high grain yield/plant under water stress in the two cycles was 17.49 and $5.83 \%$ for cycle 1 and 32.57 and $16.57 \%$ for cycle 2 from the unselected bulk sample and the better parent, respectively. These results indi- cated that selection for high grain yield/plant under water stress from the $F_{4}$ generation was more effective than selection from $F_{3}$. This may due to the increase of level of homozygosity in the $\mathrm{F}_{4}$ generation, and it was easy to identify the genetically superior genotypes. Therefore, results suggest delaying selection for grain yield/plant to the $F_{4}$ generation, till homozygosity reach acceptable level to save costs, effort and avoid loss of the best genotypes.

The second cycle selection was evaluated under both environments. The observed gain in normal irrigation group were (19.58 and $23.67 \%)$ from bulk sample and $(7.93$ and $8.75 \%$ ) from the better parent compared to (26.44 and 32.57) from bulk sample and (14.13 and 16.57\%) from the better parent for water stress group under normal irrigation and water stress, respectively It is obvious that selection under water stress was better than selection under normal irrigation. In other words antagonistic selection for grain yield was better than synergistic selection.

\subsection{Drought susceptibility index and sensitivity to environments:}

The drought susceptibility index (DSI) and sensitivity to environments of the selected families for grain yield/plant are presented in Table 8 . The results of the selected families for two cycles under normal irrigation (normal group) when evaluated under both environments indicated that five families, i.e., No. 9, No. 44, No. 49, No. 62 and No. 72 showed drought susceptibility index (DSI) of $0.87,0.53,0.69,0.92$ and 0.68 , respectively. The five families which gave DSI less than one, gave 
also values less than one (less sensitive) in sensitivity test. These families could be used as source of drought tolerance. Furthermore, it could be noticed that three superior families, No. 9, No. 49 and No. 72 were less susceptible and less sensitive to drought and showed significant observed gain over the better parent under normal irrigation and water stress. These families could be promising families. The results of families which selected under water stress and evaluated under both environments showed that, five families, No. 20 , No. 42, No. 45, No. 51 and No. 61 gave drought susceptibility index of $0.54,0.78,0.75,0.90$ and 0.89 , indicating less susceptibility. All these families gave also values less than one in sensitivity test. Sids 1 showed less susceptibility, however, Misr 1 and the bulk sample were susceptible. It is of interest to indicate that the three superior families, i.e., No. 45 No. 51 and No. 61 were less susceptible and less sensitive to drought and showed significant observed gain over the better parent under normal irrigation and water stress. The mean sensitivity to drought of the selected families for high grain yield/plant under normal irrigation was 0.99 , while it was 0.96 for the selected families under deficit water (Table 8).

The relative merit after two cycles of selection for high grain yield was 1.35 when selection was under normal and water deficit and evaluation under normal irrigation, while it was 1.37 when selection was under normal and water deficit and evaluation under water stress.

Table 8. Drought susceptibility index (DSI) and sensitivity (S) to environments of selected families under normal irrigation and water stress after two cycles of selection for grain yield/plant.

\begin{tabular}{|c|c|c|c|c|c|c|c|c|c|}
\hline \multicolumn{10}{|c|}{ Environment of selection } \\
\hline \multicolumn{5}{|c|}{ Normal irrigation selections } & \multicolumn{5}{|c|}{ Water stress selections } \\
\hline Fam. No. & $\mathbf{N}$ & D & DSI & $\mathbf{S}$ & Fam. No. & $\mathbf{N}$ & D & DSI & $\mathbf{S}$ \\
\hline 1 & 24.29 & 19.95 & 1.29 & 1.28 & 10 & $29.62 * *$ & $25.15 * *$ & 1.19 & 1.31 \\
\hline 9 & $25.80 *$ & $22.68 *$ & 0.87 & 0.92 & 16 & 22.98 & 19.82 & 1.09 & 0.93 \\
\hline 44 & 21.78 & 20.19 & 0.53 & 0.47 & 17 & $25.29^{*}$ & 19.78 & 1.72 & 1.62 \\
\hline 49 & $26.54 * *$ & $24.00^{* *}$ & 0.69 & 0.75 & 18 & 23.62 & 20.36 & 1.09 & 0.96 \\
\hline 56 & $28.71 * *$ & $23.10^{* *}$ & 1.41 & 1.65 & 20 & 24.98 & $23.27 * *$ & 0.54 & 0.50 \\
\hline 62 & 20.96 & 18.28 & 0.92 & 0.79 & 27 & 24.72 & 21.45 & 1.05 & 0.96 \\
\hline 72 & $26.39^{* *}$ & $23.89 * *$ & 0.68 & 0.73 & 42 & 24.66 & $22.21 *$ & 0.78 & 0.72 \\
\hline 77 & $25.57^{*}$ & 21.41 & 1.18 & 1.23 & 45 & $26.83 * *$ & $24.30 * *$ & 0.75 & 0.74 \\
\hline 92 & 23.39 & 19.06 & 1.34 & 1.27 & 51 & $25.71 *$ & $22.79 *$ & 0.90 & 0.86 \\
\hline 98 & 20.29 & 17.40 & 1.03 & 0.85 & 61 & $29.30^{* *}$ & $26.00^{* *}$ & 0.89 & 0.97 \\
\hline average & 24.37 & 21.00 & & 0.99 & Mean & $25.77 *$ & $22.51 *$ & & 0.96 \\
\hline Sids 1 & 21.36 & 19.31 & 0.69 & 0.60 & Sids 1 & 21.36 & 19.31 & 0.69 & 0.60 \\
\hline Misr 1 & 22.58 & 18.35 & 1.36 & 1.25 & Misr 1 & 22.58 & 18.35 & 1.36 & 1.25 \\
\hline Bulk & 20.38 & 16.98 & 1.20 & & Bulk & 20.38 & 16.98 & 1.20 & \\
\hline
\end{tabular}

$\mathrm{N}=$ normal irrigation

$\mathrm{D}=$ water stress

$\mathrm{S}=$ sensitivity

* and **; significant observed gain from the better parent at 0.05 and 0.05 level of probability; respectively.

These results indicate that the antagonistic selection was better than synergistic selection to increase grain yield/plant in these materials, either evaluation made under normal irrigation or under water stress. However, 
the antagonistic selection reduced sensitivity to drought stress while, synergistic selection increased it. These results were in agreement with that found by Jinks and Connolly (1973 and 1975) on Schizophyllum Commune, Jinks and Pooni (1982) on Nicotiana rustica., Ceccarelli and Grando (1991 a and b) on barley and Mohamed (2001) on cotton. Falconer (1990) stated that, when selection and environment change the character in opposite direction this is antagonistic selection, i.e. selection upwards in a low environment or downwards in a high environment. Synergistic selection is the reverse; upwards in a high environment or downwards in a low environment, when selection and environment change the character in the same direction. Kheiralla et al. (2006) found that selection under early planting (synergistic selection) increased sensitivity of the selected families, while selection under late planting (antagonistic selection) decreased it. Mahdy (2012) found that the antagonistic selection was better than synergistic selection to increase grain yield/plant either evaluation made under normal irrigation or under drought stress and the antagonistic selection reduced sensitivity of the selected families, while the synergistic selection increased it.

\subsection{The phenotypic correlation af- ter two cycles of selection for grain yield/plant:}

The phenotypic correlations among traits after two cycles of selection for grain yield/plant under normal irrigation and water stress are shown in Table 9. After two cycles of selection the coefficients of phenotypic correlation under normal irriga- tion between grain yield/plant and each of days to heading, days to maturity, plant height, number of spikes/plant, number of kernels/spike, 100-kernel weight and biological yield/plant were $0.468,0.441 .0 .196$, $0.847,0.519,0.134$ and 0.930 , respectively. These results indicate that the most effective components in grain yield of wheat would be number of spikes/plant, number of kernels/spike and biological yield/plant. This means that, selection played on the highest correlated trait with grain yield/plant (number of spikes/plant, number of kernels/spike and biological yield/plant) in the base population.

The coefficients of phenotypic correlation under water stress were $0.368,0.205,0.354,0.762,0.600$, 0465 and 0.810 between grain yield/plant and the above mentioned traits, respectively. These results indicated that selection under water stress increased the correlation between grain yield and each of number of kernels/spike and 100-kernel weight and turned the correlation between number of kernels/spike and 100-kernel weight from insignificant negative to insignificant positive.

Positive genotypic correlation was recorded between yield and each of number of spikes/plant (Ahmed 2006, Sharma et al. 2006, Anawar et al., 2009), biological yield/plant (khan et al. 2010, Moustafa, 2015 and Khames, et al. 2016). Mahdy (2012) indicated that high and positive phenotypic correlation between grain yield/plant and each of number of spikes/plant and biological yield/plant under normal irrigation and drought stress. 
2.9. Path coefficient analysis in base population $\left(F_{3}\right)$ and after two cycles $\left(F_{5}\right)$ of selection for grain yield/ plant:

The Partitioning of phenotypic correlation into direct and indirect effects by path analysis under normal irrigation revealed that the highest direct effect on grain yield/plant was exerted by number of spikes/plant in base population 0.673 and in cycle two of selection 0.813 (Table 10). Moreover, the highest indirect effects were correlated also with number of spikes/plant across the base population 0.272 and cycle two of selection 0.132 via number of kernels/spike. These results suggested that number of spikes/plant has exhibited to be powerful traits as a yield component and must be given preference in selection to improve grain yield/plant. It is clear that the effect of residual factor was decreased from 0.173 in base to 0.071 in the second cycle of selection. Consequently, the strong effects were found for current studied traits on grain yield/plant of wheat.

The Partitioning of phenotypic correlation into direct and indirect effects by path analysis under water stress revealed that the highest direct effect on grain yield/plant was exerted by number of kernels/spike in base population 0.586 and by number of spikes/plant in cycle two of se- lection 0.690 (Table 10). Moreover, the highest indirect effects were correlated also with number of spikes/plant across the base population and cycle two of selection. The estimates of these indirect effects were 0.167 and 0.070 via 100 -kernel weight followed by 0.119 and 0.052 via number of kernels/spike in base population and cycle two, respectively. These results, indicated that the direct effect of number of spikes/plant exhibited superiority on grain yield /plant for selection in the cycle two of selection compared to their base population. It concluded that the number of spikes/plant followed by number of kernels/spike and 100-kernel weight are important for selection of high yielding in wheat.

Different estimates of direct and indirect effects of yield components on grain yield of wheat revealed by many studies according the studied populations such as Kashif and Khaliq (2004), Abd El-Mohsen and Abd El-Shafi (2014), Nasri et al. (2014), Khames et al. (2016). Abd El-Kareem (2014) indicated that the most important sources of variation in grain yield are the direct effect of number of spikes/plant followed by number of kernels/spike and 100kernel weight under water stress conditions. 
Table 9. Phenotypic correlation among the studied traits for the $F_{5}$ generation under normal (above diagonal) and water stress (below diagonal) conditions.

\begin{tabular}{|c|c|c|c|c|c|c|c|c|}
\hline Trait & DH & DM & PH & NS/P & NK/S & 100KW & GY/P & BY/P \\
\hline DH & & $0.845^{* *}$ & 0.360 & $0.496^{*}$ & 0.275 & -0.273 & $0.468^{*}$ & $0.573^{* *}$ \\
\hline DM & $0.834^{* *}$ & & 0.109 & $0.476^{*}$ & 0.161 & -0.166 & 0.441 & $0.528^{*}$ \\
\hline PH & 0.425 & 0.213 & & 0.248 & 0.088 & -0.202 & 0.196 & 0.242 \\
\hline NS/P & 0.392 & 0.127 & 0.379 & & 0.162 & -0.122 & $0.847^{* *}$ & $0.695^{* *}$ \\
\hline NK/S & 0.338 & 0.352 & 0.186 & 0.075 & & -0.282 & $0.519^{*}$ & $0.570^{* *}$ \\
\hline $\mathbf{1 0 0 K W}$ & -0.278 & -0.225 & -0.157 & 0.102 & 0.118 & & 0.134 & 0.195 \\
\hline GY/P & 0.368 & 0.205 & 0.354 & $0.762^{* *}$ & $0.600^{* *}$ & $0.465^{*}$ & & $0.930^{* *}$ \\
\hline BY/P & 0.225 & 0.240 & 0.307 & 0.433 & $0.699^{* *}$ & 0.365 & $0.801^{* *}$ & \\
\hline
\end{tabular}

*** Significant at 5 and $1 \%$ levels of probability, respectively.

Table 10. Partitioning of phenotypic correlation coefficients into direct and indirect effects by path coefficient analysis for base population $\left(F_{3}\right)$ and cycle two $\left(F_{5}\right)$ of pedigree selection for grain yield /plant under normal and water stress conditions.

\begin{tabular}{|c|c|c|c|c|c|}
\hline \multirow[b]{2}{*}{ Correlation } & & \multicolumn{2}{|c|}{$\begin{array}{c}\text { Normal } \\
\text { irrigation }\end{array}$} & \multicolumn{2}{|c|}{ Water stress } \\
\hline & & $\begin{array}{l}\text { Base } \\
\text { pop. } \\
\left(\mathrm{F}_{3}\right)\end{array}$ & $\begin{array}{c}\text { Cycle } \\
\text { two }\left(F_{5}\right)\end{array}$ & $\begin{array}{c}\text { Base } \\
\text { pop. } \\
\left(F_{3}\right)\end{array}$ & $\begin{array}{c}\text { Cycle } \\
\text { two }\left(F_{5}\right)\end{array}$ \\
\hline 1- Number of spikes/plant vs. Grain & $\mathbf{r}$ & 0.851 & 0.847 & 0.728 & 0.762 \\
\hline Direct effect & $\mathbf{P}_{14}$ & 0.673 & 0.813 & 0.453 & 0.690 \\
\hline Indirect effects via number of kernels/spike & $\mathbf{r}_{12} \mathbf{P}_{24}$ & 0.218 & 0.080 & 0.154 & 0.038 \\
\hline \multirow[t]{2}{*}{ Indirect effects via 100-kernel weight } & $\mathbf{r}_{13} \mathbf{P}_{34}$ & -0.040 & -0.046 & 0.121 & 0.034 \\
\hline & Total & 0.851 & 0.847 & 0.728 & 0.762 \\
\hline 2-Number of kernels/spike vs. Grain & $\mathbf{r}$ & 0.698 & 0.519 & 0.777 & 0.600 \\
\hline Direct effect & $\mathbf{P}_{24}$ & 0.539 & 0.493 & 0.586 & 0.508 \\
\hline Indirect effects via number of spikes/plant & $\mathbf{r}_{12} \mathbf{P}_{14}$ & 0.272 & 0.132 & 0.119 & 0.052 \\
\hline \multirow[t]{2}{*}{ Indirect effects via 100-kernel weight } & $\mathbf{r}_{23} \mathbf{P}_{34}$ & -0.113 & -0.106 & 0.072 & 0.040 \\
\hline & Total & 0.698 & 0.519 & 0.777 & 0.600 \\
\hline 3-100-kernel weight vs. Grain yield/plant & $\mathbf{r}$ & 0.064 & 0.134 & 0.625 & 0.465 \\
\hline Direct effect & $\mathbf{P}_{34}$ & 0.329 & 0.372 & 0.330 & 0.335 \\
\hline Indirect effects via number of spikes/plant & $\mathbf{r}_{13} \mathbf{P}_{14}$ & -0.081 & -0.099 & 0.167 & 0.070 \\
\hline \multirow[t]{3}{*}{ Indirect effects via number of kernels/spike } & $\mathbf{r}_{23} \mathbf{P}_{24}$ & -0.184 & -0.139 & 0.128 & 0.060 \\
\hline & Total & 0.064 & 0.134 & 0.625 & 0.465 \\
\hline & $1-R^{2}$ & 0.97 & 0.995 & 992 & 0.984 \\
\hline \multicolumn{2}{|l|}{ Residual factor } & 0.173 & 0.071 & 0.089 & 0.126 \\
\hline
\end{tabular}




\section{References}

Abd El-Kader, M.N.T. 2011. Selection for yield and some quality traits in durum wheat (Triticum turgidum var. durum). Ph.D. Thesis, Fac. Agric., Assiut Univ., Egypt.

Abd El-Kareem, Thanaa, H.A. 2014. Phenotypic, genotypic correlation and path coefficient analysis in two bread wheat crosses under water stress conditions. Egypt. J. Plant Breed. 18(1):71 - 81.

Abd El-Mohsen, A.A. and M.A. Abd ElShafi. 2014. Regression and path analysis in Egyptian bread wheat. J. of Agri. Food and Applied Sci., 2 (5): 139-148.

Abd-El-Haleem, S.H.M., Ehab, M.R. Metwali and S.M.S. Mohamed. 2012. Efficiency of pedigree Selection in bread wheat under drought stress conditions. Life Sci. J. 9 (4): 3423-3429.

Ahmed, A.A.S., M.A. El-Morshidy, K.M. R.Kheiralla, R. Uptmoor, M.A. Ali and N.E.M. Mohamed. 2014. Selection for drought tolerance in wheat population (Triticum aestivum L.) by Independent culling levels. World J. Agric. Res. 2 (2): $56-62$.

Ahmed, T.A. 2006. Efficiency of late and early selection for grain yield under different selection criteria and DNA marker Polymorphism in wheat (Triticum aestivum L.). Assiut J. Agric. Sci. 37 (2): 1-16.

Ali, M.A. 2011. Pedigree selection for grain yield in spring wheat (Triticum aestivum L.) under drought stress conditions. Asian J. Crop Sci. 3 (4): 158-168.

Al-Jibouri, H.A., P.A. Miller and H.F. Robinson. 1958. Genotypic and environmental variance and covariance in an Upland cotton cross of interspecific origin. Agron. J. 50: 633-636.
Amin-Alim, M. 2011. The effects of water and heat stress on wheat. Agric. Trop. Et Subtropical 44 (1): 44-47.

Anwar, J.; M.A. Ali; M. Hussain; W. Sabir; M.A. Khan; M. Zulkiffal and M. Abdullah. 2009. Assessment of yield criteria in bread wheat through correlation and path analysis. The J. of Anim. \& Pl. Sci., 19: 185-188.

Attia, I.A. 2003. Selection for drought tolerance in wheat. Ph.D. Thesis, El-Minia Univ., Egypt.

Betran, F.J., D. Beck, M. Banziger and G.O. Edmeades 2003. Genetic analysis of inbred and hybrid grain yield under stress and non stress environments in tropical maize. Crop Sci. J. 43 (3): 807817.

Burton, G.W. 1952. Quantitative inheritance in grasses. Proceeding of $6^{\text {th }}$ International Grassland Congress, Vol. 1, Pennsylvania State College, 17-23 August 1952, 277-283.

Byrne P.F., J. Bolanos, G.O. Edmeades and D.L Eaton. 1995. Gains from selection under drought versus multiplication testing in related tropical maize populations. Crop Sci. J. 35 (1): 63-69.

Ceccarelli, S. and S. Grando. 1991a. Selection environment and environmental sensitivity in barley. Euphytica 57 (2): 157-167.

Ceccarelli, S. and S. Grando 1991b. Environment of selection and type of germplasm in barley breeding for low-yielding conditions. Euphytica 57 (3): 207-219.

Cheema, N.M., M.A. Mian, M. Ihsan, G. Rabbani and A. Mahmood. 2006. Studies on variability and some genetic parameters in spring wheat. Pak. J. Agri. Sci. 43: 32-35.

Dewey, D.R. and K.H. Lu. 1959. A correlation and path coefficient analysis of components of crested wheat 
grass seed production. Agron. J. 51: 515-518.

Economic Affairs Sector, Ministry of Agricultural and Land reclamation, Egypt. Annual report. 2015.

El-Morshidy, M.A., K.A. Kheiralla, M.A. Ali and A.A. Said. 2010. Response to selection for earliness and grain yield in wheat (Triticum aestivum L.) under normal and water stress conditions. Assiut J. Agric. Sci. 41: 1-23.

El-Rawi, K. and A.M. Khalafala. 1980. Design and Analysis of Agricultural Experiments. El-Mousel Univ. Iraq.

Falconer, D.S. 1989. Introduction to Quantitative Genetics. $3^{\text {rd }}$ ed. Longman, Hong Kong, pp 438.

Falconer, D.S. 1990. Selection in different environment: effects on environmental sensitivity (reaction norm) and mean performance. Genetical Research 56 (1): 57-70.

Fischer, R.A. and R. Maurer. 1978. Drought resistance in spring wheat cultivars. I. Grain yield response. Crop and Pasture Sci. 29 (5): $897-$ 912.

Ismail, A.A. 1995. Pedigree selection for grain yield, grain weight and earliness in two segregating populations of spring wheat. Assiut J. Agric. Sci. 24: 59-72.

Jinks, J.L. and H.S. Pooni. 1982. Determination of the environmental sensitivity of selection lines of Nicotiana rustica by selection environment. Heredity 49 (3): 291294.

Jinks, J.L. and V. Connolly. 1973. Selection for specific and general response to environmental differences. Heredity 30: 33-40.

Jinks, J.L. and V. Connolly. 1975. Determination of environmental sensitivity of selection lines by the selection environment. Heredity 34 (3): 401-406.
Kashif, M. and I. Khaliq. 2004. Heritability, correlation and path coefficient analysis for some metric traits in wheat. Int. J. Agri. Bio. 6 (1): 138-142.

Khames, K.M., A. Abo-Elwafa, A.M. Mahmoud and A. Hamada 2016. Correlation, Path-coefficient, Normal and Stepwise Regression Analyses Via Two Cycles of Pedigree Selection in Bread Wheat (Triticum aestivum L). Assiut J. Agric. Sci. 47:84-108.

Khan, A.J., F. Azam and A. Ali. 2010. Relationship of morphological traits and grain yield in recombinant inbred wheat lines grown under drought conditions. Pak. J. Bot., 42: 259-267.

Kheiralla, K.A. 1993. Selection response for grain yield and its components in a segregating population of spring wheat. Assiut J. Agric. Sci. 24:87-98.

Kheiralla, K.A., M.A. El-Morshidy, A.M. Tammam and M.M. Zakaria. 2006. The efficiency of selection and environmental sensitivity for grain yield in wheat. Symposium: Status and Improvement Horizons of Field Crops in the Arab World. 30-31 October, 2006, Alepo Univ., Syria.

Mahdy E.E., A.E. El-Karamity, S.A. Mokadem and H.M. Fouad 2012. Selection for grain yield and its components in two segregating populations. Minia Int. Conf. Agric. Irrig. In the Nile Basin Coun., $26^{\text {th }}-29^{\text {th }}$ March 2012, p. 595-604.

Mahdy, Rasha, E. 2012. Response to selection for earliness and yield in bread wheat under normal and drought conditions. Ph.D. Thesis, Fac. Agric. Assiut Univ., Egypt.

Mohamed, A. A. 2001. Breeding for earliness and yield components in some Egyptian cotton crosses. 
PhD. Thesis Fac. Agric. Assiut Univ. Assiut, Egypt.

Moustafa, H.M.F, 2015. Single and multiple traits selection in bread wheat under normal and drought stress conditions. Ph.D. Thesis, Fac. of Agric., Minia Univ., pp. 166.

Nasri, R.; A. Kashani; F. Paknejad; S.Vazan and M. Barary. 2014. Correlation, path analysis and stepwise regression in yield and yield component in wheat (Triticum aestivum L.) under the temperate climate of Ilam Province, IRAN. Indian J. of Fundamental and Applied Life Sci. 14 (4): 188198.

O'Brien, L.; R.J. Baker and L.E. Evans.1978. Response to selection for yield in F3 of four wheat crosses. Crop Sci. 18: 1029-1033.

Passioura, J. 2007. The drought environment: physical, biological and agricultural perspectives. J. Exp. Bot. 58 (2): 113-117.

Rathjen, A.J. 1994. The biological basis of genotype environment interaction Its definition and management. In Proceedings of the Seventh Assembly of the Wheat Breeding Society of Australia, Adelaide, Australia.

Salous, M.SH., M.A. El-Morshidy, K.A. Kheiralla and M.Kh. Moshref. 2014. Selection for grain yield in bread wheat (triticum aestivum 1.) Under normal and heat stress conditions. Assiut j. of Agric. Sci. 45:1-18.

Sharma, V., I.S. Pawar and R. Munjal. 2006. Variability parameters, cor- relation and path coefficients for yield, its components and quality traits in bread wheat. Nat. J. Pl. Improv., 8: 153-155.

Soliman G.M.M., M.A. El-Morshidy, K.A. Kheiralla and I.A. Amin. 2015. Selection efficiency under both normal irrigation and water deficit conditions in durum wheat. Egypt. J. Agric. Res. 93 (2): 335351.

Steel, R.G.D. and J.H. Torrie. 1980. Principle and Procedures of Statistics. A Biometrical approach $2^{\text {nd }}$ Ed., McGraw-Hill Book Company, New York. U.S.A.

Tammam, A.M., M.S.F. El-Ashmoony, A.A. El-Sherbeny and I.A. Amin. 2004. Selection responses for drought tolerance in two bread wheat crosses. Egypt J. Agric. Res. 82 (3): 1213-1226.

Walker, T.T. 1960. The use of a selection index technique in the analysis of progeny row data. Emp. Cott. Rev. 37: 81-107.

Zakaria, M.M. 2004. Selection for earliness and grain yield in bread wheat (Triticum aestivum L.) under different environmental conditions. Ph.D. Thesis, Fac. of Agric. Assiut Univ., Egypt.

Zakaria, M.M., M.A. El-Morshidy, K.A. Khieralla and A.M. Tammam. 2008. Direct selection for grain yield and correlated response in bread wheat under normal and late sowing dates. Assiut J. of Agric. Sci. 39:1-16. 
كفاءة الاتخاب لمحصول الحبوب تحت ظروف الري العادي والإجهاد المائي في قمح الخبز

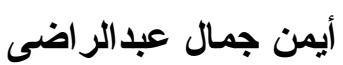

قسم بحوث القمح - معهد بحوث المحاصيل الحقلية - مركز البحوث الزراعية

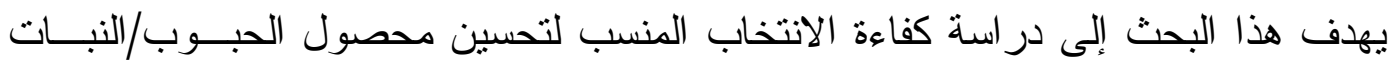

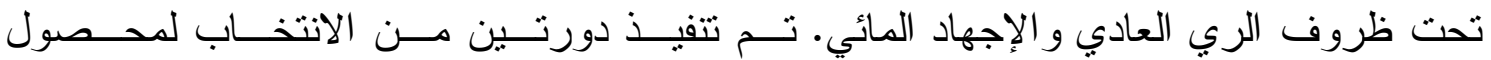

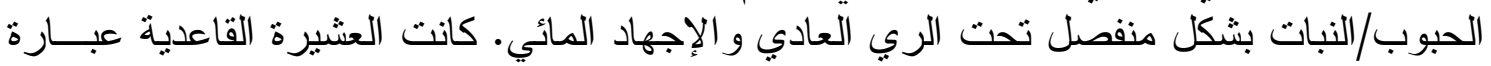

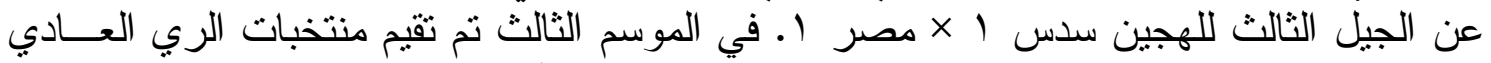

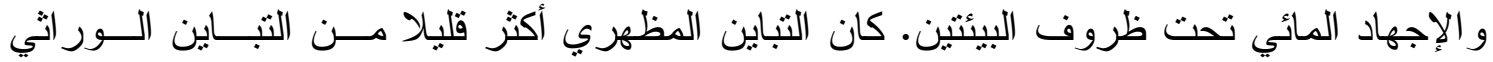

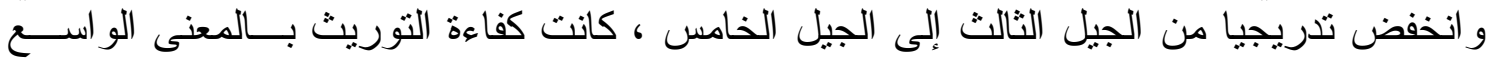

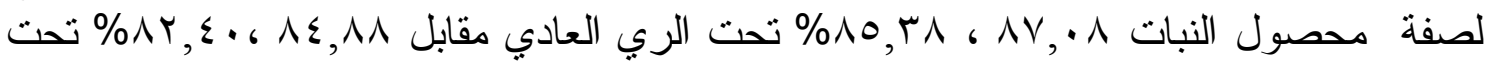

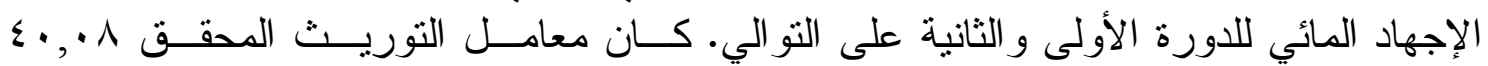

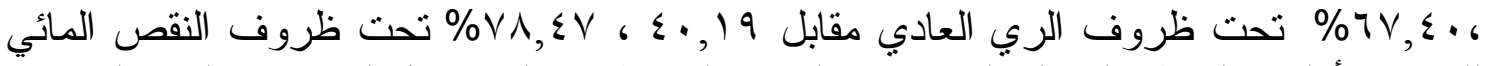

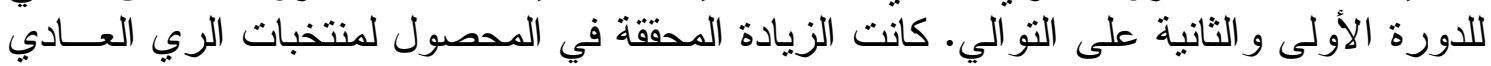

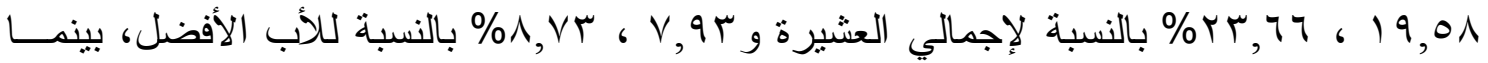

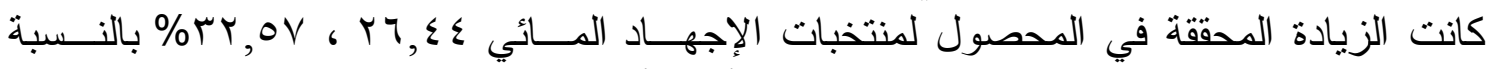

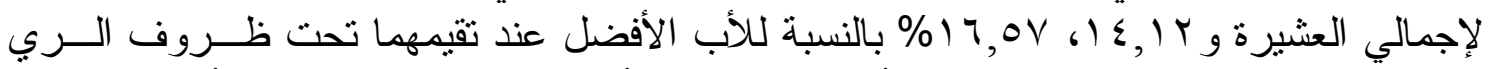

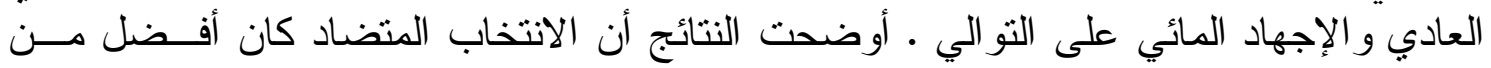

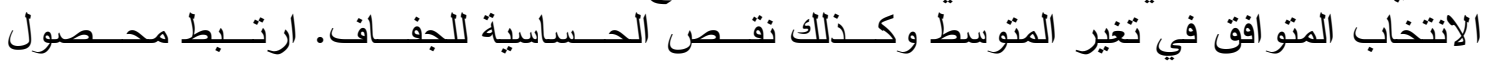

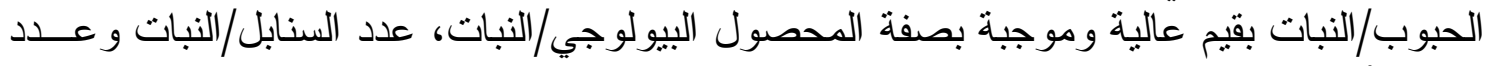

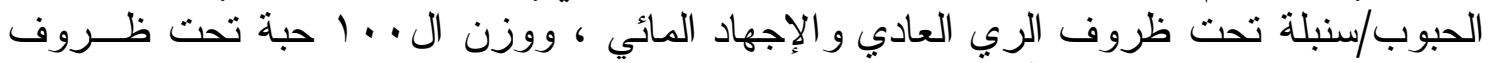

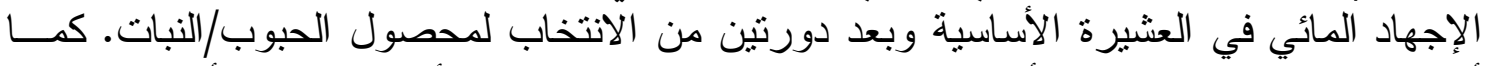

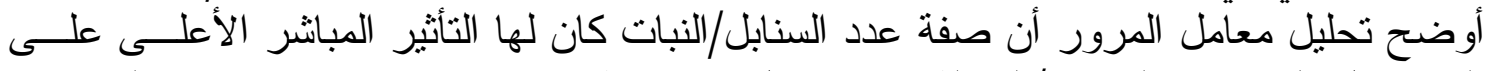

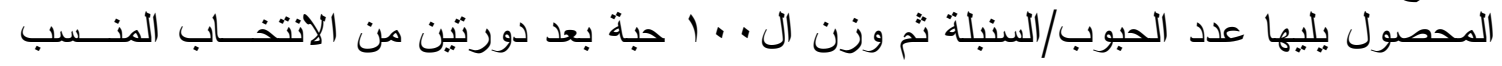
لمحصول الحبوب/النبات تحت ظروف الريلة فري العادي و الإجهاد المائي. 